\title{
Does Weather Forecasting Relate to Foraging Productivity? An Empirical Test among Three Hunter-Gatherer Societies ${ }^{\mathscr{a}}$
}

\author{
VICTORIA REYES-GARCÍA \\ Institució Catalana de Recerca i Estudis Avançats, and Institut de Ciència i Tecnologia Ambientals, \\ Universitat Autònoma de Barcelona, Barcelona, Spain \\ ÁlVARO FERNÁNDEZ-LlamAZARES \\ Metapopulation Research Centre, Department of Biosciences, University of Helsinki, Helsinki, Finland \\ MAXIMILIEN GUÈZE \\ Institut de Ciència i Tecnologia Ambientals, Universitat Autònoma de Barcelona, Barcelona, Spain \\ SANDRINE GALLOIS \\ Faculty of Archaeology, Leiden University, Leiden, Netherlands
}

(Manuscript received 19 June 2017, in final form 27 September 2017)

\begin{abstract}
Previous research has studied the association between ethnoclimatological knowledge and decision-making in agriculture and pastoral activities but has paid scant attention to how ethnoclimatological knowledge might affect hunting and gathering, an important economic activity for many rural populations. The work presented here tests whether people who can forecast temperature and rain display higher hunting and gathering returns (measured as kilograms per hour for hunting and cash equivalent for gathering). Data were collected among three indigenous, small-scale, subsistence-based societies largely dependent on hunting and gathering for their livelihoods: the Tsimane' (Amazonia, $n=107$ ), the Baka (Congo basin, $n=164$ ), and the Punan Tubu (Borneo, $n=103)$. The ability to forecast rainfall and temperature varied from one society to another, but the average consistency between people's 1-day rainfall and temperature forecasts and instrumental measurements was low. This study found a statistically significant positive association between consistency in forecasting rain and the probability that a person engaged in hunting. Conversely, neither consistency in forecasting rain nor consistency in forecasting temperature were associated in a statistically significant way with actual returns to hunting or gathering activities. The authors discuss methodological limitations of the approach, suggesting improvements for future work. This study concludes that, other than methodological issues, the lack of strong associations might be partly explained by the fact that an important characteristic of local knowledge systems, including ethnoclimatological knowledge, is that they are widely socialized and shared.
\end{abstract}

\section{Introduction}

Ethnoclimatological knowledge refers to the comprehensive system of insights, experiences, and practices regarding climate, local weather events, and their

\footnotetext{
Supplemental information related to this paper is available at the Journals Online website: https://doi.org/10.1175/WCAS-D-170064.s1.

Corresponding author: Victoria Reyes-García, victoria.reyes@ uab.cat
}

changes at different spatiotemporal scales developed by indigenous peoples and local communities (Orlove et al. 2000). Interest in ethnoclimatology dates back to the end of the last century (e.g., Pepin 1996; Sillitoe 1994; Sollod 1990) but gained momentum after Orlove et al.'s (2000) seminal work unraveling the connection between stargazing and potato planting among Quechua and Aymara farmers. Orlove and his colleagues found that farmers in Peru and Bolivia forecasted the most auspicious time to plant potatoes by looking, around midJune, at the brightness, apparent size, and position of the Pleiades, one of the brightest star clusters in the Taurus 
constellation. The dimmer the Pleiades, as determined by their apparent size and brilliance, the less rain in the area to be expected 6 months later. Based on such observations, farmers would delay potato planting to reduce crop damage. The novelty of the study lied in contrasting folk observations with scientific records. Climatologists had previously determined that El Niño-Southern Oscillation (ENSO) events influence rainfall in the Andes but had not realized that ENSO events also affected stellar visibility in June (most likely caused by the presence of thin cirrus clouds obscuring them). Conversely, Andean farmers, drawing on careful long-term observations, and despite being unaware of the scientific explanations for the events, had made the connection between shifts in Pleiades brightness in June and rain fluctuations.

Ethnoclimatology has grown during the last two decades with many works detailing how local observations of the environment, such as animals' behavior, changes in plants' morphology and physiology, patterns in clouds' and winds' formation and properties, or other climatic and biological phenomena, are used to forecast immediate and future weather (e.g., Kijazi et al. 2013; Lefale 2010) as well as climate change impacts (Reyes-García et al. 2016a). Beyond the description of traditional climatic knowledge systems, some works have also aimed to complement such observations with meteorological information (Fernández-Llamazares et al. 2017; Roncoli et al. 2002), often highlighting the unique contribution of ethnoclimatological knowledge to climate research (Kalanda-Joshua et al. 2011; King et al. 2007; Marin 2010; Roncoli et al. 2002). A large part of this research has also aimed to discuss how ethnoclimatological knowledge is used to deal with the uncertainties of climate conditions affecting people's livelihoods (Bjornstadt 2016) and how this information could be of help for improving livelihoods under current local and global social-ecological challenges (Green et al. 2010; Kolawole et al. 2016; Mapfumo et al. 2016; Risiro et al. 2012).

A pattern in this literature is its focus on the association between ethnoclimatological knowledge and agriculture and pastoral decision-making. Agriculture is highly sensitive to changes in weather conditions, for which the anticipation of the arrival of the rainy season, the amount and intensity of rainfall, or the occurrence of frosts and droughts are of great importance to ensure agricultural production (Altieri and Koohafkan 2008). Consequently, many works describe diverse traditional climate prediction skills that influence the decisions and practices associated with crop growth cycles, crop varieties selection, and other agronomic activities (Brondizio and Moran 2008; Jiri et al. 2016; Moran et al. 2006; Osunade 1994; Soropa et al. 2015). For example, Kolawole et al. (2016) studied how rural households in the Okavango delta (Botswana) use local knowledge to predict the weather and thus overcome the vagaries of weather patterns by taking measures such as selecting and preserving drought-resistant or early maturing seeds or deciding changes in farming calendars. Other works describe climate prediction skills of pastoralist communities (e.g., Ayal et al. 2015; Luseno et al. 2003) and how this knowledge is being used to detect changes in climate. For example, Marin (2010) analyzed ethnoclimatological knowledge of Mongolian pastoral nomads who reported longer and more intense droughts and sandstorms than in the past. Their responses contrasted with climatologists' models predicting the warming of the region, probably because pastoralists focused on events that were relevant to their livelihood.

Less research has focused on hunting and gathering, productive activities that could also be affected by peoples' abilities to forecast weather. Indeed, to date, the relation between weather forecasting and subsistence hunting has been primarily studied in the Arctic, most notably in the context of climate change (Krupnik and Jolly 2002; Krupnik et al. 2010; Pearce et al. 2015). A growing body of scholarly work highlights how increasingly unpredictable weather in the Arctic undermines access to important subsistence resources, with deep implications in food security (e.g., Ford et al. 2006; Brinkman et al. 2016; Rosol et al. 2016). Considering that environmental income, or the diversity of goods provided freely from noncultivated ecosystems, makes up to $28 \%$ of the total income of rural households in the tropics (Angelsen et al. 2014), analyzing the association between ethnoclimatological knowledge and decision-making in hunting and gathering activities seems important, at least for rural households in the tropics.

While agricultural and pastoralist activities are probably more affected by the ability to accurately forecast seasonal weather changes, as the Orlove et al. (2000) study suggests, hunting and gathering are probably more affected by the ability to accurately forecast weather in the very short term (i.e., within hours or days). In this sense, at least one study conducted among the Tsimane' hunter-gatherers of the Bolivian Amazon suggests that daily weather affects how people allocate their time between alternative activities (Godoy et al. 2009). Hunters might decide to cancel their hunting expeditions if they forecast a windy day, as the wind carries human smell making it difficult to approach the prey (Hansen et al. 2013), or if they forecast a rainy day because rainfall affects hunter's ability to see and/or hear wild game. Similarly, people might postpone a gathering expedition if they forecast a very hot day, given that high temperatures can make the expedition uncomfortable. As such, accurate prediction of rainfall and temperature might increase the likelihood of successful hunting and gathering. 
TABLE 1. Climatic and geographic characteristics of the studied sites.

\begin{tabular}{|c|c|c|c|}
\hline Studied society & Tsimane' & Baka & Punan Tubu \\
\hline Sample & $\begin{array}{l}257 \text { forecast from } \\
107 \text { informants }\end{array}$ & $\begin{array}{c}264 \text { forecasts from } \\
164 \text { informants }\end{array}$ & $\begin{array}{c}176 \text { forecasts from } \\
103 \text { informants }\end{array}$ \\
\hline Latitude & $\begin{array}{l}14^{\circ} 10^{\prime}-15^{\circ} 40^{\prime} \mathrm{S} \\
\quad 66^{\circ} 20^{\prime}-67^{\circ} 20^{\prime} \mathrm{W}\end{array}$ & $\begin{array}{l}3^{\circ} 5^{\prime}-7^{\circ} 26^{\prime} \mathrm{N} \\
14^{\circ} 3^{\prime}-14^{\circ} 44^{\prime} \mathrm{E}\end{array}$ & $\begin{array}{l}3^{\circ} 0^{\prime}-3^{\circ} 20^{\prime} \mathrm{N} \\
\quad 116^{\circ} 0^{\prime}-116^{\circ} 15^{\prime} \mathrm{E}\end{array}$ \\
\hline Elevation & $250-300 \mathrm{~m}$ & $300-600 \mathrm{~m}$ & $400-600 \mathrm{~m}$ \\
\hline Mean annual rainfall (SD) & $1743 \mathrm{~mm}$ & $1500 \mathrm{~mm}$ & 2000 to $4000 \mathrm{~mm}$ \\
\hline Mean annual temperature (SD) & $25^{\circ} \mathrm{C}$ & $25^{\circ} \mathrm{C}$ & $27^{\circ} \mathrm{C}$ \\
\hline Rainy season & $1 \mathrm{Dec}$ to $31 \mathrm{Mar}$ & 20 Aug to $30 \mathrm{Nov}$ & $1 \mathrm{Dec}$ to $28 \mathrm{Feb}$ \\
\hline Forecasts collected during rainy season & $180($ or $70 \%)$ & $73($ or $28 \%)$ & $74($ or $42 \%)$ \\
\hline
\end{tabular}

Since the ability to accurately forecast weather does change from one person to another (Kolawole et al. 2016), one would expect that people with better forecasting abilities would be better at selecting among different foraging activities and their location, which could potentially result in an overall increase in hunting and gathering productivity. We test this prediction using data from a cross-cultural study in three indigenous, small-scale, subsistence-based societies: the Tsimane' (Amazonia), the Baka (Congo basin), and the Punan Tubu (Borneo).

\section{The case studies}

The three studied societies resemble one another in that they depend on the consumption of local natural resources through a combination of hunting, gathering, and farming in an environment where they have historical continuity of resource use. They also resemble one another in that - to date-they have relatively little (albeit increasing and uneven) involvement in market economies, school-based education, or modern healthcare systems (Reyes-García et al. 2016b). In the three societies, people are largely free to take decisions on how to allocate their time between different subsistence activities, as few of them work a wage. They also mostly rely on their local knowledge to forecast weather, as mass media (i.e., radio, TV) do not reach the areas or only give regional or national weather forecasts. None of the studied societies have culturally recognized specialists in forecasting weather, for which ethnoclimatological knowledge might be largely considered lay (i.e., not specialized) knowledge. Below we provide some glimpses of the three studied societies and their environment and climatological regimes (see also Table 1).

The Tsimane' are a small-scale indigenous society of foragers and farmers in the Bolivian Amazon. The Tsimane' inhabit a densely forested region between the foothills of the Andes and the savannas of Moxos, within altitudinal ranges of $150-300 \mathrm{~m}$. The climate of the region is tropical, with a rainy season from December to March and a marked dry season from April to October with less than $100 \mathrm{~mm}$ of rainfall and punctual cold spells from June to August (Fernández-Llamazares et al. 2017). Annual-mean temperature is $25.8^{\circ} \mathrm{C}$ and annualmean precipitation is $1743 \mathrm{~mm}$ (Guèze et al. 2013).

Nowadays, the Tsimane' number $\sim 12000$ people living in $\sim 100$ villages of $\sim 20$ households, concentrated along rivers and logging roads (Reyes-García et al. 2014). Up until the late 1930s, the Tsimane' maintained a traditional and self-sufficient lifestyle. However, their interactions with the Bolivian society steadily increased since the 1940s (Reyes-García et al. 2014). Previously seminomadic, they are now mostly settled in permanent villages with schools. Tsimane' rely on subsistence agriculture and hunting, fishing, and gathering, supplemented with wage labor in logging camps and cattle ranches. Some households also sell some crops (i.e., rice, maize, and plantain) and barter thatch palm (Vadez et al. 2008).

Hunting and gathering are the basis of Tsimane' subsistence (Luz et al. 2015). The Tsimane' hunt at least 29 vertebrate species (Luz 2013). Hunting was traditionally done with bow and arrow, but rifles and shotguns are more frequent now. Dogs are also used to locate and corner wounded animals (Chicchón 1992; Luz 2013). Hunting can take place at both day and night in planned incursions deep in the forest, but adequate weather conditions are essential for hunting success, given that animals are more difficult to spot on extremely hot days or under heavy rain. Men usually gather together early in the morning and exchange impressions about locations, animal presence, and weather conditions before deciding their daily activities. The gathering of wild resources occurs year-round and is usually performed in household collective expeditions involving children from an early age, for which Tsimane' try to avoid them if they expect a hot and/or rainy day (Fernández-Llamazares et al. 2016). 
Our second study society, the Baka, is one of the hunter-gatherer groups indigenous to the tropical rain forests of the Congo basin. Numbering between 30000 and 40000 , most Baka live in southeastern Cameroon, in an area covered by a mixture of evergreen and moist semideciduous forest within altitudinal ranges of $300-600 \mathrm{~m}$. The climate of the region is tropical humid, with a major rainy season between late-August and late-November and a major dry season between late-November and mid-March. Minor rainy and dry seasons occur between mid-March and September. Mean annual temperature in the area is $25^{\circ} \mathrm{C}$, and annual-mean precipitation is $1500 \mathrm{~mm}$ (Leclerc 2012; Yasuoka 2012).

Traditionally, the Baka lived in seminomadic groups, largely dependent on wild resources, although they also have a long history of mutual interdependence with neighboring sedentary farmers (Bahuchet 1993). At the turn of the 1960s, following the decline of elephant populations and missionary's attempts to sedentarize them, the Baka regrouped along logging roads and started to adopt agriculture, an activity that modified their spatial and temporal organization (Leclerc 2012). Nowadays, the Baka continue to move between villages and forest camps and maintain strong material and symbolic relations with farmers. Most Baka combine hunting-gathering with work for their farming neighbors, wild products trade, and cultivation of cassava and plantains, their major staple crops. Overall, the Baka economic system is experiencing an increasing monetization and commoditization (Kitanishi 2006).

Baka hunting targets a low diversity of relatively abundant species (i.e., small duikers, porcupines, and rats) and a relatively low share of large game (Duda 2017). Hunting techniques include unearthing burrowing animals (i.e., Gambian pouched rat) with fire and smoking them out from their nests to be caught using spears and machetes. The hunt of large mammals (i.e., elephant or primates) requires specific social and technical organization (Joiris 1998; Bahuchet 1992). Baka hunters have started to adopt more efficient hunting techniques, such as steel cable snares and 12-gauge shotguns (Yasuoka 2014), which have changed the species targeted (Fa et al. 2016). Over the year, the Baka engage in 1- or 2-day expeditions to hunt and collect wild edibles (Duda 2017), but during the major rainy season they also engage in weeks-long expeditions to hunt large mammals and gather marketable wild edibles (such as wild mango). According to the Baka, some meteorological conditions shape their decisions to go foraging. For example, setting snares or dog hunting is preferably done after a rainy day, as the animal's footprints are easier to locate in humid soil. However, among the Baka, foraging success is often linked to the notion of "luck," affected by social, spiritual, and ritual aspects (Joiris 1998).

The third study group, the Punan Tubu, live in the mountainous interior of Indonesian Borneo, in an extremely steep and irregular terrain dominated by old-growth forest. Climate in the area is tropical, with relatively constant average temperatures all year-round (around $27^{\circ} \mathrm{C}$ ). Annual rainfall ranges from 2000 to $4000 \mathrm{~mm}$, usually with more than $100 \mathrm{~mm}$ monthly and with a peak of rainfall in December-February (Gueze and Napitupulu 2017; MacKinnon et al. 1996). The annual climatic regime is strongly dependent on ENSO, which determines years with extreme events such as drought or flooding caused by heavy rainfall (MacKinnon et al. 1996).

Punan Tubu traditional livelihood was largely based on preparing starch from sago palms, hunting bearded pigs, and bartering with the locally settled farmers (Kaskija 2012). The Punan Tubu started to shift to a more sedentary lifestyle during the mid-1950s under pressures from government programs (Kaskija 2012). At present, the Punan distributed in Malinau and Mentarang districts number between 3500 and 4000, with upstream populations of about 1200 (Sellato 2007). Although the Punan Tubu are no longer nomadic, they still engage in long travels and seasonal stays in the forest for hunting wild boars and gathering wild edibles and other forest products for sale (i.e., eaglewood, hornbill heads, or bezoar stones; Kaskija 2012; Levang et al. 2007). Other than income from the sale of nontimber forest products, wage labor-including work in government projectsprovides a significant and regular income for many Punan Tubu nowadays (Napitupulu et al. 2016).

Hunting continues to be crucial in Punan Tubu diet as it provides most of their protein intake. Blowpipes, the traditional hunting weapon, are nowadays seldom used but other traditional hunting techniques, such as spears and dogs, are still preferred for large game species. Men mostly hunt during 1- or 2-day forest expeditions (Gueze and Napitupulu 2017), and women and children often help, carrying heavy animals from kill sites. The planning of these expeditions (whether individual or group bouts) occurs in the early morning and usually involves discussions among different households. Regarding gathering, although most sago palm groves are no longer exploited, other wild edibles such as wild mangoes (Mangifera spp.), durians (Durio spp.), and rambutans (Nephelium spp.) remain an important part of the Punan Tubu diet (Kaskija 2012). The Punan Tubu exploit several species of rattan (Calamus spp.), which they use to craft mats and baskets. Currently the most valuable forest product in the area is gaharu, or eaglewood, the 
fungi-infected part of Aquilaria spp. used in the perfumery industry.

\section{Materials and methods}

The work presented here was conducted under the framework of a large research project on the adaptive nature of culture (see Reyes-García et al. 2016b). Before collecting any data, we obtained free prior and informed consent from each village and individual participating in the study as well as agreement from the relevant political organization representing the indigenous groups. The empirical work presented here is based on 18 months of fieldwork among the described societies, where we worked with local research assistants. During the first 6 months, we invested in building trust with participants and collecting ethnographic data on local livelihoods. We also conducted focus group discussions and semistructured interviews with key informants regarding techniques, division of labor, seasonality, and assets associated with subsistence activities. We used this information to construct a questionnaire on people's abilities to forecast local weather, which was implemented during the last 12 months of the research (see the supplemental information).

\section{a. Sampling}

In each society, we worked with two villages settled at a different distance to the market town. Within each village, we worked with all adults ( $>16$ years of age) willing to participate (participation rate $>90 \%$ ). A total of 391 adults (107 Tsimane', 164 Baka, and 103 Punan Tubu) provided forecasts. To capture seasonal variation we visited informants up to three times over the course of a calendar year (August 2012 to August 2013). The fieldwork period seemed to be within the normal climatic range, as there were no mentions of infrequent climate phenomena in any of the societies. In total, we obtained 697 observations (257 from Tsimane', 264 from Baka, and 176 from Punan Tubu), which included both rain and temperature forecasts. Because hunting and gathering techniques and returns vary across seasons, reportedly being more difficult during the rainy than during other seasons, we collected forecasts in different moments. Among the Tsimane', 70\% of the forecasts were collected during the rainy season (153 days); the percentage was lower among the Baka $(28 \%)$ and the Punan Tubu (42\%), where the rainy seasons are also shorter (83 and 93 days respectively; Table 1).

\section{b. Data collection and variable construction}

Consistency of weather forecasting with instrumental records was measured by contrasting information on individual weather forecasts and daily weather, as recorded by a meteorological station. We collected instrumental weather data with a computerized weather station and a pluviometer installed in each study village. For security and convenience reasons, we installed the equipment near the researchers' houses, nearby the village center. The weather station was set in the shade and the pluviometer in an open area (i.e., no forest cover or construction in a 50-m diameter). Each day of researcher's presence in the village, we recorded (i) total rain and (ii) maximum and (iii) minimum temperature. We proxied short-term weather forecasting skills by asking informants to predict rain and temperature for the following day. Specifically, we asked, "Do you think it will rain tomorrow?" and "Do you think tomorrow is going to be colder than today?" We tried-to the extent it was possible-to ask the question casually, as part of a daily conversation.

We then constructed a measure of consistency by comparing individual weather forecasting with instrumental weather data. "Consistency" was coded as 1 if a person's response matched the instrumental data and 0 if it did not match. If the participant did not know or did not answer, consistency was set to missing. For temperature, we took the average between the maximum and minimum temperature for the day of the interview and the previous day. We considered that the previous day was colder $(=1)$ if the average temperature was lower than the average temperature during the day of the interview. For rainfall, we considered the informant's answer as consistent if the response on whether it had rained (yes or not) matched the record or any rain versus no rain at all in the pluviometer. As we have several forecasts per individual, our consistency variable corresponds to the share of answers in which the forecasts matched the instrumental record. For each person we constructed two consistency measures, one for rainfall and one for temperature. To describe the data, we coded consistency as low if $<33 \%$ matches with instrumental data, medium if $(33 \%>$ consistency $<67 \%)$, and high if $>67 \%$ matches (Table 2), but in regression analyses we used the actual share of matchings as an explanatory variable. Note that the term consistency, as used here, fairly resembles to the term verification in forecasting parlance, but we prefer to avoid the latter, given that the term lies at the very intersection of the tensions between scientific and local knowledge, posing a number of deep epistemological challenges (see Tengö et al. 2014). So, we use the term consistency to navigate the agreements and disagreements between both forms of knowledge, without implying that one is more valid than another.

To collect data on foraging productivity, we used an anthropological technique known as scan observations (Reyes-García et al. 2009). Each week, on a day chosen at random, we visited each household and asked adults 
TABLE 2. Percentage of informants with rainfall/temperature forecasts consistent with instrumental data, by consistency level $(n=374)$

\begin{tabular}{|c|c|c|c|c|}
\hline & Tsimane' & Baka & Punan Tubu & Total \\
\hline & \multicolumn{4}{|c|}{ Rainfall } \\
\hline Low $(<33 \%)$ & 42.1 & 67.1 & 32.0 & 55.1 \\
\hline Medium $(33 \%-67 \%)$ & 32.7 & 13.4 & 31.1 & 20.2 \\
\hline \multirow[t]{2}{*}{ High $(>67 \%)$} & 25.2 & 19.5 & 36.9 & 24.7 \\
\hline & \multicolumn{4}{|c|}{ Temperature } \\
\hline Low $(<33 \%)$ & 55.1 & 62.6 & 38.1 & 54.0 \\
\hline Medium $(33 \%-67 \%)$ & 42.1 & 37.4 & 61.9 & 45.2 \\
\hline $\operatorname{High}(>67 \%)$ & 2.8 & 0.0 & 0.0 & 0.8 \\
\hline$N$ & 107 & 164 & 103 & 336 \\
\hline
\end{tabular}

about their main activities during the previous 2 days. If they reported hunting, we asked about the animals killed and the duration of the hunting expeditions; if they reported gathering, we asked about the forest products brought to the household during the previous $24 \mathrm{~h}$ and the duration of the trip. Since we repeated the interview over the course of a year, we obtained an average of $19.2 \mathrm{ob}-$ servations per person [standard deviation (SD) 6.9]. Because, to reduce informant's fatigue, we tried to sparse our visits to a household, there is no overlap between the dates when forecasting and foraging productivity were measured.

Hunting returns were proxied as the kilograms of meat obtained per hour invested in hunting $\left(\mathrm{kg} \mathrm{h}^{-1}\right)$, including trap preparation and unsuccessful trips. As it was not always possible to obtain the weight of the preys, we used published data to estimate the weight of different animals [mostly Kingdon (1997) and Gautier-Hion et al. (1999) for central Africa, Payne and Francis (2007) for Borneo, and Myers et al. (2006) for Bolivian Amazon]. In our estimations, we differentiated between the weight of males and females. We assigned the value of half the weight of the same sex adult to any juvenile specimen reported. Gathering returns were measured as the monetary equivalent of forest products brought to the household the $24 \mathrm{~h}$ prior to the interview. We calculated the monetary equivalent of the forest products gathered to be able to aggregate the diversity of products mentioned. We used the market price to value the goods. For goods without a price we used the price of the closest substitute. For crosscountry comparisons, we used purchasing power parity (PPP) exchange rates. Thus, all monetary values express PPP-adjusted U.S. dollars, and our measure is in PPP U.S. dollars per $24 \mathrm{~h}$.

At the beginning of the study, we conducted a census in each village to collect information on household composition and individual's age, sex, and maximum school grade. We also collected data on two standard economic variables: wealth and income. Individual wealth was measured as the value of a set of market items owned by the subject, and income was measured as the sum of cash income from the sale of wild meat and agricultural and forest products plus income from wage labor (see Reyes-García et al. 2016b). Information to construct the income measure comes from quarterly individual interviews, with a recall of 2 weeks and averaged to obtain a single measure for each individual. Monetary values for wealth and income are expressed in PPP-adjusted U.S. dollars.

\section{c. Data analysis}

We start by describing data on consistency between forecasting and instrumental data. We then explore the socioeconomic correlates of our measures of consistency by running a Tobit regression with our measures of consistency as dependent variable and a set of standard socioeconomic variables (i.e., age, sex, household size, maximum school grade, wealth, and income) as potential explanatory variables while controlling for village fixed effects (Table 3). We selected a Tobit model because the variable consistency was not normally distributed but censored, and Tobit multivariate models are the most appropriate to predict an outcome in a censored dependent variable.

Our main analysis consists of exploring how consistency in forecasting relates to hunting and gathering returns. We do so by running separate regressions for hunting and gathering (dependent variables) and alternatively using consistency in forecasting rainfall and temperature (explanatory variables). For example, to test the association between consistency in forecasting rain and hunting returns, we use expression (1):

$$
[1] H_{i h v}=\alpha+\gamma \mathrm{CR}_{i h v}+\beta \mathbf{P}_{i h v}+\lambda \mathbf{M}_{i h v}+\Omega S+\varepsilon_{i h v},
$$

where $H$ corresponds to the kilograms per hour hunted by subject $i$ of household $h$ in village $v$, and CR is our measure of consistency between a person's rainfall forecasts and instrumental data. The term $\mathbf{P}_{i h v}$ is a vector of variables to control for sociodemographic characteristics of the person (i.e., sex, age, household size, and schooling), which also includes a control for the use of traditional weapons versus shotguns. The term $\mathbf{M}_{i h v}$ is a vector that includes controls for economic characteristics of informants (i.e., wealth and income). In our core model (model 1; Table 4), we control for societies fixed effects or invariant characteristics that might affect the estimated association by including a set of dummies for the society of study $(S)$. In a second model (model 2), we run the same exact 
TABLE 3. Tobit regression estimating the socioeconomic correlates of the measures of consistency $(\mathrm{n}=310)$. Note the standard errors in parentheses:. AIC stands for Akaike information criterion and BIC stands for Bayesian information criterion. AIC and BIC are two popular measures for comparing maximum likelihood models combining fit and complexity.

\begin{tabular}{|c|c|c|}
\hline & (1) & (2) \\
\hline & Rainfall & Temperature \\
\hline Male $(=1)$ & $\begin{array}{c}0.2276 \\
(0.1420)\end{array}$ & $\begin{array}{c}-0.013 \\
(0.076)\end{array}$ \\
\hline Age (in years) & $\begin{array}{c}-0.0060^{*} \\
(0.0032)\end{array}$ & $\begin{array}{c}-0.003 \\
(0.005)\end{array}$ \\
\hline Household size & $\begin{array}{c}-0.0127 \\
(0.0406)\end{array}$ & $\begin{array}{c}-0.035 \\
(0.022)\end{array}$ \\
\hline Schooling (in grades) & $\begin{array}{c}0.0365 \\
(0.0376)\end{array}$ & $\begin{array}{c}0.021 \\
(0.037)\end{array}$ \\
\hline \multirow{2}{*}{$\begin{array}{l}\text { Individual wealth } \\
\text { (in PPP-adjusted U.S. dollars) } \\
\text { Income } \\
\text { (in PPP-adjusted U.S. dollars) }\end{array}$} & $\begin{array}{c}-0.0001 * * \\
(0.0001)\end{array}$ & $\begin{array}{c}0.0001 \\
(0.0000)\end{array}$ \\
\hline & 0.0000 & $-0.0004 *$ \\
\hline \multicolumn{3}{|c|}{ Village dummies (Punan Tubu village 2 omitted category) } \\
\hline Tsimane' village $1,(=1)$ & $\begin{array}{c}-0.6400 * * * \\
(0.1817)\end{array}$ & $\begin{array}{c}-0.833^{* * * *} \\
(0.170)\end{array}$ \\
\hline Tsimane' village $2,(=1)$ & $\begin{array}{l}0.4243 * * * \\
(0.1357)\end{array}$ & $\begin{array}{l}0.228^{* *} \\
(0.093)\end{array}$ \\
\hline Baka village $1,(=1)$ & $\begin{array}{c}-0.3988^{* * * *} \\
(0.1151)\end{array}$ & $\begin{array}{l}-0.471 * * * \\
(0.134)\end{array}$ \\
\hline Baka village $2,(=1)$ & $\begin{array}{c}-1.5098 * * * \\
(0.3751)\end{array}$ & $\begin{array}{c}-0.655^{* * * *} \\
(0.170)\end{array}$ \\
\hline Punan Tubu village $1,(=1)$ & $\begin{array}{l}0.4499 * * * \\
(0.1188)\end{array}$ & $\begin{array}{c}-0.126^{* *} \\
(0.050)\end{array}$ \\
\hline Constant & $\begin{array}{l}0.5761 * * \\
(0.2819)\end{array}$ & $\begin{array}{l}0.591 * * * \\
(0.205)\end{array}$ \\
\hline Sigma constant & $\begin{array}{l}1.0531 * * * \\
(0.3008)\end{array}$ & $\begin{array}{l}0.941 * * * \\
(0.285)\end{array}$ \\
\hline$N$ & 310 & 310 \\
\hline Pseudo $R^{2}$ & 0.100 & 0.06 \\
\hline AIC & 604.0863 & 591.8909 \\
\hline $\mathrm{BIC}$ & 622.7691 & 610.5737 \\
\hline
\end{tabular}

$* p<0.10$.

$* * p<0.05$.

$* * * p<0.01$.

regression but include a set of village (rather than society) dummies to control for village fixed effects. The term $\varepsilon_{i h v}$ is the error term or the information that remains unexplained by the model. All regressions also include village clusters to indicate that the observations may be correlated within villages but independent between them. Before running our main regressions, we calculated the variance inflation factors (VIFs) to assess potential collinearity among variables (not shown). The VIFs value obtained, 1.16, was safely below the value of 10 used to detect problematic multicollinearity (Hair 2010), indicating that multicollinearity was not a problem.
As our dependent variables were not normally distributed, but zero inflated and positively skewed (meaning that many people returned home empty handed), we used a two-part model with the same dependent and independent variables to reduce estimation biases associated with such distribution (McElreath and Koster 2014). The first part uses a logit binary choice model to estimate the probability that the person has some returns to her investment in hunting versus no returns at all. The second part models the relation between weather forecasting and hunting returns only for the observations in which people actually had some returns.

We then use the same expression but with our measure of consistency in temperature, again testing for society (model 3) and village fixed effects (model 4). Finally, we add the two explanatory variables in the same model (models 5 and 6). We use exactly the same approach to test the association between consistency in forecasting and gathering returns (Table 5). As an indicator of statistical significance, we report $\mathrm{p}$ values $<$ 0.10 . For the statistical analysis, we used the statistical software package Stata for Windows, version 13.

\section{Results}

\section{a. Consistency with instrumental data}

The average consistency between people's forecast of the following day rainfall and temperature and results obtained in our meteorological stations was generally low. Only $25 \%$ of informants had high (i.e., $>67 \%$ matches) levels of consistency on rain forecast, with a higher percentage among the Punan Tubu (37\%; Table 2). Results from a Chi2 test (not shown) suggest that there is an association between the individual consistency measures from forecasting rain and temperature $(p<0.001)$, with $27.5 \%$ of informants having low (i.e., $<33 \%$ matches) average consistency measures for both rain and temperature forecast and $15.3 \%$ having medium average consistency levels.

Overall, consistency between rainfall and temperature forecasts and records from instrumental data is mostly dependent on the informant's village of residency, as none of the other variables used in our Tobit analysis is consistently associated with consistency (Table 3). Younger people $(p<0.10)$ and people with lower levels of wealth $(p<0.50)$ seem to have lower consistency levels for rainfall, whereas higher income appears weakly $(p<0.10)$ associated with lower consistency levels in forecasting temperature (Table 3). Conversely, the variables that capture village residency are statistically significant. The two Baka villages and the less isolated Tsimane' village display lower levels of consistency than the most isolated Punan Tubu village, 
TABLE 4. Two-part model estimating the association between consistency in forecasting (rain and temperature) and hunting returns. (See the notes for Table 3.)

\begin{tabular}{|c|c|c|c|c|c|c|}
\hline \multirow[b]{2}{*}{ Explanatory variable } & Model 1 & Model 2 & Model 3 & Model 4 & Model 5 & Model 6 \\
\hline & \multicolumn{2}{|c|}{ Consistency rainfall } & \multicolumn{2}{|c|}{ Consistency temperature } & \multicolumn{2}{|c|}{$\begin{array}{c}\text { Consistency rainfall and } \\
\text { temperature }\end{array}$} \\
\hline Fixed effect & Society & Village & Society & Fixed effect & Society & Village \\
\hline \multicolumn{7}{|c|}{ Logit model } \\
\hline Consistency rainfall & $\begin{array}{l}0.904 * * \\
(0.401)\end{array}$ & $\begin{array}{r}0.821 * \\
(0.460)\end{array}$ & & & $\begin{array}{l}0.962 * * \\
(0.467)\end{array}$ & $\begin{array}{r}0.875^{*} \\
(0.507)\end{array}$ \\
\hline Consistency temperature & & & $\begin{array}{c}-0.134 \\
(0.437)\end{array}$ & $\begin{array}{l}-0.301 \\
(0.461)\end{array}$ & $\begin{array}{r}-0.321 \\
(0.490)\end{array}$ & $\begin{array}{c}-0.420 \\
(0.502)\end{array}$ \\
\hline Male & $\begin{array}{l}2.635^{* * * *} \\
(0.552)\end{array}$ & $\begin{array}{l}2.703 * * * \\
(0.599)\end{array}$ & $\begin{array}{l}2.632 * * * \\
(0.550)\end{array}$ & $\begin{array}{l}2.686^{* * *} \\
(0.616)\end{array}$ & $\begin{array}{l}2.644 * * * \\
(0.560)\end{array}$ & $\begin{array}{l}2.714 * * * \\
(0.615)\end{array}$ \\
\hline Age & $\begin{array}{c}-0.016 \\
(0.012)\end{array}$ & $\begin{array}{c}-0.015 \\
(0.013)\end{array}$ & $\begin{array}{c}-0.019 \\
(0.013)\end{array}$ & $\begin{array}{c}-0.017 \\
(0.013)\end{array}$ & $\begin{array}{c}-0.016 \\
(0.012)\end{array}$ & $\begin{array}{c}-0.016 \\
(0.013)\end{array}$ \\
\hline Household size & $\begin{array}{l}-0.116^{* *} \\
(0.048)\end{array}$ & $\begin{array}{l}-0.103^{* *} \\
(0.047)\end{array}$ & $\begin{array}{l}-0.111^{* *} \\
(0.046)\end{array}$ & $\begin{array}{c}-0.099 * * \\
(0.045)\end{array}$ & $\begin{array}{l}-0.118 * * \\
(0.049)\end{array}$ & $\begin{array}{l}-0.107 * * \\
(0.047)\end{array}$ \\
\hline Schooling & $\begin{array}{c}-0.193 \\
(0.150)\end{array}$ & $\begin{array}{c}-0.188 \\
(0.166)\end{array}$ & $\begin{array}{l}2.824 * * * \\
(0.784)\end{array}$ & $\begin{array}{l}2.838 * * * \\
(0.786)\end{array}$ & $\begin{array}{l}2.908 * * * \\
(0.734)\end{array}$ & $\begin{array}{l}2.930 * * * \\
(0.722)\end{array}$ \\
\hline Individual wealth & $\begin{array}{l}0.0004 * * \\
(0.0002)\end{array}$ & $\begin{array}{l}0.0004 * * \\
(0.0002)\end{array}$ & $\begin{array}{c}-0.179 \\
(0.140)\end{array}$ & $\begin{array}{c}-0.162 \\
(0.147)\end{array}$ & $\begin{array}{c}-0.194 \\
(0.150)\end{array}$ & $\begin{array}{c}-0.188 \\
(0.164)\end{array}$ \\
\hline Income & $\begin{array}{c}-0.0000 \\
(0.0002)\end{array}$ & $\begin{array}{c}-0.0001 \\
(0.0002)\end{array}$ & $\begin{array}{l}0.0003 * \\
(0.0002)\end{array}$ & $\begin{array}{l}0.0003 * * \\
(0.0002)\end{array}$ & $\begin{array}{l}0.0004 * * \\
(0.0002)\end{array}$ & $\begin{array}{l}0.0004 * * \\
(0.0002)\end{array}$ \\
\hline Use traditional weapon & $\begin{array}{l}2.918 * * * \\
(0.721)\end{array}$ & $\begin{array}{l}2.938 * * * \\
(0.718)\end{array}$ & $\begin{array}{c}0.0000 \\
(0.0002)\end{array}$ & $\begin{array}{c}-0.0001 \\
(0.0002)\end{array}$ & $\begin{array}{c}-0.0000 \\
(0.0002)\end{array}$ & $\begin{array}{c}-0.0001 \\
(0.0002)\end{array}$ \\
\hline Tsimane' & $\begin{array}{l}2.827 * * * \\
(0.438)\end{array}$ & & $\begin{array}{l}2.597 * * * \\
(0.490)\end{array}$ & & $\begin{array}{l}2.789 * * * \\
(0.470)\end{array}$ & \\
\hline Baka & $\begin{array}{l}2.865 * * * \\
(0.453)\end{array}$ & & $\begin{array}{l}2.521 * * * \\
(0.501)\end{array}$ & & $\begin{array}{l}2.831 * * * \\
(0.455)\end{array}$ & \\
\hline Tsimane' village 1 & & $\begin{array}{l}2.402 * * * \\
(0.339)\end{array}$ & & $\begin{array}{l}2.061 * * * \\
(0.443)\end{array}$ & & $\begin{array}{l}2.310^{* * * *} \\
(0.404)\end{array}$ \\
\hline Tsimane' village 2 & & $\begin{array}{l}2.587 * * * \\
(0.431)\end{array}$ & & $\begin{array}{l}2.584 * * * \\
(0.409)\end{array}$ & & $\begin{array}{l}2.593 * * * * \\
(0.438)\end{array}$ \\
\hline Baka village 1 & & $\begin{array}{l}2.784 * * * \\
(0.282)\end{array}$ & & $\begin{array}{l}2.552 * * * \\
(0.271)\end{array}$ & & $\begin{array}{l}2.744 * * * \\
(0.291)\end{array}$ \\
\hline Baka village 2 & & $\begin{array}{l}1.803^{* * * *} \\
(0.324)\end{array}$ & & $\begin{array}{l}1.404 * * * \\
(0.156)\end{array}$ & & $\begin{array}{l}1.721^{* * * *} \\
(0.259)\end{array}$ \\
\hline Punan Tubu village 1 & & $\begin{array}{c}-0.639 * * * \\
(0.108)\end{array}$ & & $\begin{array}{c}-0.544 * * * \\
(0.121)\end{array}$ & & $\begin{array}{c}-0.642^{* * *} \\
(0.107)\end{array}$ \\
\hline _cons & $\begin{array}{c}-3.160 * * * \\
(0.595)\end{array}$ & $\begin{array}{c}-2.929 * * * \\
(0.687)\end{array}$ & $\begin{array}{c}-2.417 * * \\
(1.050)\end{array}$ & $\begin{array}{c}-2.282 * * \\
(1.141)\end{array}$ & $\begin{array}{c}-3.010 * * * \\
(0.778)\end{array}$ & $\begin{array}{c}-2.726^{* * * *} \\
(0.904)\end{array}$ \\
\hline Pseudo $R^{2}$ & 0.44 & 0.45 & 0.44 & 0.45 & 0.45 & 0.46 \\
\hline \multicolumn{7}{|c|}{ OLS regression model } \\
\hline Consistency rainfall & $\begin{array}{c}0.507 \\
(0.438)\end{array}$ & $\begin{array}{c}0.638 \\
(0.441)\end{array}$ & & & $\begin{array}{c}0.633 \\
(0.521)\end{array}$ & $\begin{array}{c}0.697 \\
(0.488)\end{array}$ \\
\hline Consistency temperature & & & $\begin{array}{c}-0.841 \\
(0.636)\end{array}$ & $\begin{array}{c}-0.755 \\
(0.636)\end{array}$ & $\begin{array}{c}-0.939 \\
(0.666)\end{array}$ & $\begin{array}{c}-0.814 \\
(0.650)\end{array}$ \\
\hline Male & $\begin{array}{c}0.378 \\
(0.510)\end{array}$ & $\begin{array}{c}0.328 \\
(0.491)\end{array}$ & $\begin{array}{c}0.390 \\
(0.545)\end{array}$ & $\begin{array}{c}0.310 \\
(0.514)\end{array}$ & $\begin{array}{c}0.395 \\
(0.578)\end{array}$ & $\begin{array}{c}0.332 \\
(0.547)\end{array}$ \\
\hline Age & $\begin{array}{c}-0.004 \\
(0.008)\end{array}$ & $\begin{array}{c}-0.001 \\
(0.011)\end{array}$ & $\begin{array}{c}-0.005 \\
(0.009)\end{array}$ & $\begin{array}{c}-0.001 \\
(0.010)\end{array}$ & $\begin{array}{c}-0.004 \\
(0.009)\end{array}$ & $\begin{array}{c}-0.0003 \\
(0.011)\end{array}$ \\
\hline Household size & $\begin{array}{c}0.040 \\
(0.043)\end{array}$ & $\begin{array}{c}0.019 \\
(0.047)\end{array}$ & $\begin{array}{c}0.034 \\
(0.046)\end{array}$ & $\begin{array}{c}0.018 \\
(0.049)\end{array}$ & $\begin{array}{c}0.034 \\
(0.042)\end{array}$ & $\begin{array}{c}0.017 \\
(0.047)\end{array}$ \\
\hline Schooling & $\begin{array}{c}-0.101 \\
(0.067)\end{array}$ & $\begin{array}{c}-0.075 \\
(0.048)\end{array}$ & $\begin{array}{c}-1.604 \\
(1.656)\end{array}$ & $\begin{array}{c}-1.551 \\
(1.723)\end{array}$ & $\begin{array}{r}-1.540 \\
(1.569)\end{array}$ & $\begin{array}{c}-1.436 \\
(1.601)\end{array}$ \\
\hline Individual wealth & $\begin{array}{c}-0.0000 \\
(0.0002)\end{array}$ & $\begin{array}{c}-0.0001 \\
(0.0002)\end{array}$ & $\begin{array}{c}-0.114 \\
(0.071)\end{array}$ & $\begin{array}{c}-0.065 \\
(0.048)\end{array}$ & $\begin{array}{c}-0.125^{*} \\
(0.070)\end{array}$ & $\begin{array}{r}-0.088^{*} \\
(0.049)\end{array}$ \\
\hline Income & $\begin{array}{l}0.001 * * * \\
(0.0003)\end{array}$ & $\begin{array}{l}0.001 * * * \\
(0.0003)\end{array}$ & $\begin{array}{r}-0.0000 \\
(0.0002)\end{array}$ & $\begin{array}{c}-0.0000 \\
(0.0002)\end{array}$ & $\begin{array}{c}0.000 \\
(0.0002)\end{array}$ & $\begin{array}{c}-0.0000 \\
(0.0002)\end{array}$ \\
\hline
\end{tabular}


TABLE 4. (Continued)

\begin{tabular}{|c|c|c|c|c|c|c|}
\hline \multirow[b]{2}{*}{ Explanatory variable } & Model 1 & Model 2 & Model 3 & Model 4 & Model 5 & Model 6 \\
\hline & \multicolumn{2}{|c|}{ Consistency rainfall } & \multicolumn{2}{|c|}{ Consistency temperature } & \multicolumn{2}{|c|}{$\begin{array}{c}\text { Consistency rainfall and } \\
\text { temperature }\end{array}$} \\
\hline Fixed effect & Society & Village & Society & Fixed effect & Society & Village \\
\hline Use traditional weapon & $\begin{array}{c}-1.475 \\
(1.588)\end{array}$ & $\begin{array}{c}-1.341 \\
(1.580)\end{array}$ & $\begin{array}{l}0.0010^{* * *} \\
(0.0003)\end{array}$ & $\begin{array}{l}0.001 * * * \\
(0.0003)\end{array}$ & $\begin{array}{l}0.001 * * * \\
(0.0003)\end{array}$ & $\begin{array}{l}0.001 * * * \\
(0.0003)\end{array}$ \\
\hline Tsimane' & $\begin{array}{c}-3.764 * * \\
(1.687)\end{array}$ & & $\begin{array}{c}-3.981 * * \\
(1.767)\end{array}$ & & $\begin{array}{c}-3.838^{* *} \\
(1.647)\end{array}$ & \\
\hline Baka & $\begin{array}{c}-3.066^{* * *} \\
(0.661)\end{array}$ & & $\begin{array}{c}-3.352 * * * \\
(0.771)\end{array}$ & & $\begin{array}{c}-3.112^{* * *} \\
(0.646)\end{array}$ & \\
\hline Tsimane' village 1 & & $\begin{array}{c}-2.744 * * \\
(1.083)\end{array}$ & & $\begin{array}{c}-3.405^{* *} \\
(1.499)\end{array}$ & & $\begin{array}{c}-3.050^{* *} \\
(1.262)\end{array}$ \\
\hline Tsimane' village 2 & & $\begin{array}{l}-2.857 * * \\
(1.164)\end{array}$ & & $\begin{array}{l}-3.024 * * \\
(1.275)\end{array}$ & & $\begin{array}{l}-2.929 * * \\
(1.189)\end{array}$ \\
\hline Baka village 1 & & $\begin{array}{c}-2.396^{* * *} \\
(0.258)\end{array}$ & & $\begin{array}{c}-2.758 * * * \\
(0.337)\end{array}$ & & $\begin{array}{c}-2.502 * * * \\
(0.285)\end{array}$ \\
\hline Baka village 2 & & $\begin{array}{c}-1.307 * * * \\
(0.283)\end{array}$ & & $\begin{array}{c}-1.898^{* * * *} \\
(0.515)\end{array}$ & & $\begin{array}{c}-1.515^{* * * *} \\
(0.354)\end{array}$ \\
\hline Punan Tubu village 1 & & $\begin{array}{l}1.520^{* * *} \\
(0.174)\end{array}$ & & $\begin{array}{l}1.388 * * * \\
(0.139)\end{array}$ & & $\begin{array}{l}1.397 * * * \\
(0.159)\end{array}$ \\
\hline _cons & $\begin{array}{l}4.680^{* *} \\
(1.959)\end{array}$ & $\begin{array}{l}3.729 * * * \\
(1.429)\end{array}$ & $\begin{array}{l}5.5218^{* * *} \\
(2.3727)\end{array}$ & $\begin{array}{l}4.650 * * \\
(1.948)\end{array}$ & $\begin{array}{l}5.0290^{* *} \\
(2.0141)\end{array}$ & $\begin{array}{l}4.110^{* * * *} \\
(1.595)\end{array}$ \\
\hline$R^{2}$ & 0.33 & 0.36 & 0.32 & 0.35 & 0.33 & 0.36 \\
\hline$N$ & 309 & 309 & 309 & 309 & 309 & 309 \\
\hline AIC & 946.2762 & 934.3756 & 948.1664 & 936.6197 & 940.8389 & 929.9194 \\
\hline $\mathrm{BIC}$ & 983.6096 & 971.7090 & 985.4998 & 973.9531 & 978.1723 & 967.2528 \\
\hline
\end{tabular}

$* p<0.10$.

$* * p<0.05$.

$* * * p<0.01$.

the village selected as the comparison term, whereas the most isolated Tsimane' village and the less isolated Punan Tubu village display higher levels of consistency.

\section{b. Consistency and hunting and gathering returns}

In the first part (Logit) of our two-part model testing, the association between consistency in forecasting rain and hunting returns (Table 4), we find that people with higher consistency had an increased log odds of 0.90 $(p<0.05)$ for obtaining some returns to their hunting effort (Table 4). In other words, individuals whose rain forecasting abilities are more consistent with instrumental data are also more likely to obtain some prey when hunting versus returning with empty hands. However, in the second part [ordinary least squares (OLS)], we do not see any statistically significant association between consistency in rainfall and hunting returns. Both the coefficient and the statistical significance of the variable that measures consistence are lower when including village (rather than society) dummies, although the association remains statistically significant (model 2 ).

Models 3 and 4 resemble models 1 and 2, except that in these models we use as explanatory variables consistency in temperature rather than consistency in rainfall.
In these models, we did not find any statistically significant association between consistency in temperature and hunting returns. Results are not substantially different when including, at the same time, the two consistency variables in the model (models 5 and 6).

Table 5 explores the same associations for gathering returns. Overall, our results show no statistically significant association between consistency in temperature (models 1 and 2) and rainfall (models 3 and 4) and the probability of obtaining some returns to investments in gathering (Logit model) or to the economic equivalent of the goods brought home (OLS model). The results remain largely the same when including both variables for consistency (i.e., rain and temperature) in the models (models 5 and 6).

\section{Discussion}

Before discussing the main findings of our work, we present some methodological caveats and limitations.

The first caveat of this work relates to the method used to assess people's ability to forecast weather. We aimed to assess people's forecasting abilities with what seemed to us as simple and straightforward questions: "Will it rain 
TABLE 5. Two-part model estimating the association between consistency in forecasting (rain and temperature) and gathering returns. (See notes for Table 3.)

\begin{tabular}{|c|c|c|c|c|c|c|}
\hline \multirow[b]{2}{*}{ Explanatory variable } & Model 1 & Model 2 & Model 3 & Model 4 & Model 5 & Model 6 \\
\hline & \multicolumn{2}{|c|}{ Consistency rainfall } & \multicolumn{2}{|c|}{ Consistency temperature } & \multicolumn{2}{|c|}{$\begin{array}{c}\text { Consistency rainfall and } \\
\text { temperature }\end{array}$} \\
\hline Fixed effect & Society & Village & Society & Village & Society & Village \\
\hline \multicolumn{7}{|c|}{ Logit model } \\
\hline Consistency rainfall & $\begin{array}{c}-1.031 \\
(0.685)\end{array}$ & $\begin{array}{c}-0.531 \\
(0.943)\end{array}$ & & & $\begin{array}{r}-0.789 \\
(0.853)\end{array}$ & $\begin{array}{c}-0.235 \\
(1.042)\end{array}$ \\
\hline Consistency temperature & & & $\begin{array}{c}-1.308 \\
(0.800)\end{array}$ & $\begin{array}{r}-0.595 \\
(0.953)\end{array}$ & $\begin{array}{c}-1.107 \\
(0.945)\end{array}$ & $\begin{array}{c}-0.545 \\
(1.156)\end{array}$ \\
\hline Male & $\begin{array}{l}-1.007 * * * \\
(0.332)\end{array}$ & $\begin{array}{c}-0.861 * * \\
(0.381)\end{array}$ & $\begin{array}{l}-1.168 * * * \\
(0.306)\end{array}$ & $\begin{array}{c}-0.983 * * \\
(0.393)\end{array}$ & $\begin{array}{l}-1.095 * * * \\
(0.302)\end{array}$ & $\begin{array}{l}-0.953^{* *} \\
(0.376)\end{array}$ \\
\hline Age & $\begin{array}{c}0.021 \\
(0.025)\end{array}$ & $\begin{array}{c}0.011 \\
(0.022)\end{array}$ & $\begin{array}{c}0.021 \\
(0.022)\end{array}$ & $\begin{array}{c}0.009 \\
(0.026)\end{array}$ & $\begin{array}{c}0.019 \\
(0.023)\end{array}$ & $\begin{array}{c}0.009 \\
(0.026)\end{array}$ \\
\hline Household size & $\begin{array}{r}-0.065 \\
(0.154)\end{array}$ & $\begin{array}{c}-0.010 \\
(0.153)\end{array}$ & $\begin{array}{c}-0.048 \\
(0.145)\end{array}$ & $\begin{array}{c}-0.057 \\
(0.204)\end{array}$ & $\begin{array}{c}-0.060 \\
(0.160)\end{array}$ & $\begin{array}{c}-0.058 \\
(0.206)\end{array}$ \\
\hline Schooling & $\begin{array}{c}-0.066 \\
(0.086)\end{array}$ & $\begin{array}{l}-0.160^{* *} \\
(0.076)\end{array}$ & $\begin{array}{c}-0.067 \\
(0.062)\end{array}$ & $\begin{array}{l}-0.190 * * * \\
(0.048)\end{array}$ & $\begin{array}{c}-0.063 \\
(0.068)\end{array}$ & $\begin{array}{l}-0.187 * * * \\
(0.044)\end{array}$ \\
\hline Individual wealth & $\begin{array}{c}-0.0002 \\
(0.0003)\end{array}$ & $\begin{array}{c}-0.0003 \\
(0.0003)\end{array}$ & $\begin{array}{c}-0.0001 \\
(0.0003)\end{array}$ & $\begin{array}{r}-0.0003 \\
(0.0003)\end{array}$ & $\begin{array}{c}-0.0001 \\
(0.0003)\end{array}$ & $\begin{array}{c}-0.0003 \\
(0.0003)\end{array}$ \\
\hline Income & $\begin{array}{l}-0.001 * * * \\
(0.0004)\end{array}$ & $\begin{array}{r}-0.001 * * \\
(0.0003)\end{array}$ & $\begin{array}{c}-0.001 * * * \\
(0.0004)\end{array}$ & $\begin{array}{c}-0.001 * * * \\
(0.0002)\end{array}$ & $\begin{array}{l}-0.001 * * * \\
(0.0004)\end{array}$ & $\begin{array}{l}-0.001 * * * \\
(0.0002)\end{array}$ \\
\hline Use traditional weapon & $\begin{array}{l}-1.006 \\
(0.992)\end{array}$ & & $\begin{array}{l}-1.116 \\
(1.076)\end{array}$ & & $\begin{array}{c}-1.146 \\
(0.993)\end{array}$ & \\
\hline Tsimane' & $\begin{array}{l}1.802 * * * \\
(0.666)\end{array}$ & & $\begin{array}{c}1.805^{* *} \\
-1.168 * * *\end{array}$ & $-0.983 * *$ & $\begin{array}{c}1.632 * * \\
-1.095 * * *\end{array}$ & $-0.953^{* *}$ \\
\hline Baka & & $\begin{array}{l}-2.259 * * * \\
(0.816)\end{array}$ & $\begin{array}{c}(0.306) \\
0.021\end{array}$ & $\begin{array}{c}(0.393) \\
0.009\end{array}$ & $\begin{array}{c}(0.302) \\
0.019\end{array}$ & $\begin{array}{c}(0.376) \\
0.009\end{array}$ \\
\hline Tsimane' village 1 & & & & $\begin{array}{l}1.963 * * * \\
(0.710)\end{array}$ & & $\begin{array}{l}1.9342 \text { *** } \\
(0.657)\end{array}$ \\
\hline Tsimane' village 2 & & $\begin{array}{c}-2.259 * * * \\
(0.816)\end{array}$ & & $\begin{array}{l}-1.472 * * * \\
(0.483)\end{array}$ & & $\begin{array}{l}-1.454 * * * \\
(0.509)\end{array}$ \\
\hline Baka village 1 & & $\begin{array}{c}1.166 \\
(0.956)\end{array}$ & & $\begin{array}{l}1.902 * * * \\
(0.515)\end{array}$ & & $\begin{array}{l}1.861^{* * *} \\
(0.384)\end{array}$ \\
\hline Baka village 2 & & $\begin{array}{l}0.0000 \\
(.)\end{array}$ & & $\begin{array}{l}0.0000 \\
(.)\end{array}$ & & $\begin{array}{l}0.0000 \\
(.)\end{array}$ \\
\hline Punan Tubu village 1 & & $\begin{array}{c}0.158 \\
(0.6219)\end{array}$ & & $\begin{array}{c}0.990^{*} \\
(0.571)\end{array}$ & & $\begin{array}{c}0.990^{*} \\
(0.553)\end{array}$ \\
\hline _cons & $\begin{array}{l}3.735 * * \\
(1.632)\end{array}$ & $\begin{array}{l}3.958 * * \\
(1.758)\end{array}$ & $\begin{array}{l}3.7555^{* * *} \\
(1.7014)\end{array}$ & $\begin{array}{c}3.660 * \\
(2.069)\end{array}$ & $\begin{array}{l}4.222 * * \\
(1.800)\end{array}$ & $\begin{array}{c}3.759^{*} \\
(2.152)\end{array}$ \\
\hline Pseudo $R 2$ & 0.24 & 0.31 & 0.22 & 0.33 & 0.24 & 0.33 \\
\hline \multicolumn{7}{|c|}{ OLS regression model } \\
\hline Consistency rainfall & $\begin{array}{c}-0.434 \\
(0.510)\end{array}$ & $\begin{array}{c}-0.355 \\
(0.257)\end{array}$ & & & $\begin{array}{c}-0.347 \\
(0.462)\end{array}$ & $\begin{array}{c}-0.028 \\
(0.357)\end{array}$ \\
\hline Consistency temperature & & & $\begin{array}{c}-0.631 \\
(0.576)\end{array}$ & $\begin{array}{c}0.001 \\
(0.431)\end{array}$ & $\begin{array}{c}-0.570 \\
(0.535)\end{array}$ & $\begin{array}{c}0.005 \\
(0.422)\end{array}$ \\
\hline Male & $\begin{array}{c}-0.333 \\
(0.718)\end{array}$ & $\begin{array}{c}-0.368 \\
(0.695)\end{array}$ & $\begin{array}{c}-0.376 \\
(0.733)\end{array}$ & $\begin{array}{c}-0.299 \\
(0.690)\end{array}$ & $\begin{array}{c}-0.349 \\
(0.718)\end{array}$ & $\begin{array}{c}-0.298 \\
(0.675)\end{array}$ \\
\hline Age & $\begin{array}{c}0.003 \\
(0.009)\end{array}$ & $\begin{array}{c}0.007 \\
(0.011)\end{array}$ & $\begin{array}{c}0.003 \\
(0.008)\end{array}$ & $\begin{array}{c}-0.002 \\
(0.006)\end{array}$ & $\begin{array}{c}0.003 \\
(0.008)\end{array}$ & $\begin{array}{c}-0.002 \\
(0.006)\end{array}$ \\
\hline Household size & $\begin{array}{c}-0.019 \\
(0.062)\end{array}$ & $\begin{array}{c}0.116 \\
(0.136)\end{array}$ & $\begin{array}{c}-0.028 \\
(0.062)\end{array}$ & $\begin{array}{c}-0.007 \\
(0.055)\end{array}$ & $\begin{array}{c}-0.028 \\
(0.063)\end{array}$ & $\begin{array}{c}-0.008 \\
(0.056)\end{array}$ \\
\hline Schooling & $\begin{array}{r}0.361 * \\
(0.212)\end{array}$ & $\begin{array}{r}0.371^{*} \\
(0.198)\end{array}$ & $\begin{array}{c}0.362 \\
(0.224)\end{array}$ & $\begin{array}{c}0.277 \\
(0.247)\end{array}$ & $\begin{array}{c}0.361 \\
(0.221)\end{array}$ & $\begin{array}{c}0.277 \\
(0.246)\end{array}$ \\
\hline Individual wealth & $\begin{array}{c}-0.0003 * * \\
(0.0001)\end{array}$ & $\begin{array}{c}-0.0004 * * * \\
(0.0001)\end{array}$ & $\begin{array}{c}-0.0003 * * \\
(0.0002)\end{array}$ & $\begin{array}{c}-0.0004^{* * * *} \\
(0.0001)\end{array}$ & $\begin{array}{c}-0.0003 * * \\
(0.0001)\end{array}$ & $\begin{array}{c}-0.0004 * * * \\
(0.0001)\end{array}$ \\
\hline Income & $\begin{array}{r}0.0005 \\
(0.002)\end{array}$ & $\begin{array}{c}0.004 \\
(0.003)\end{array}$ & $\begin{array}{c}0.001 \\
(0.002)\end{array}$ & $\begin{array}{c}0.002 \\
(0.002)\end{array}$ & $\begin{array}{c}0.001 \\
(0.002)\end{array}$ & $\begin{array}{c}0.002 \\
(0.002)\end{array}$ \\
\hline
\end{tabular}


TABLE 5. (Continued)

\begin{tabular}{|c|c|c|c|c|c|c|}
\hline \multirow{3}{*}{ Explanatory variable } & \multirow{2}{*}{\multicolumn{2}{|c|}{$\begin{array}{l}\text { Model } 1 \\
\text { Consistency rainfall }\end{array}$}} & \multirow{2}{*}{\multicolumn{2}{|c|}{$\begin{array}{ll}\text { Model } 3 & \text { Model } 4 \\
\text { Consistency temperature }\end{array}$}} & Model 5 & Model 6 \\
\hline & & & & & \multicolumn{2}{|c|}{$\begin{array}{c}\text { Consistency rainfall and } \\
\text { temperature }\end{array}$} \\
\hline & Society & Village & Society & Village & Society & Village \\
\hline Use traditional weapon & $\begin{array}{c}2.302 \\
(1.451)\end{array}$ & & $\begin{array}{c}2.299 \\
(1.442)\end{array}$ & & $\begin{array}{c}2.254 \\
(1.435)\end{array}$ & \\
\hline Tsimane' & $\begin{array}{c}-0.874 * * \\
(0.421)\end{array}$ & & $\begin{array}{c}-0.865 * * \\
(0.391)\end{array}$ & & $\begin{array}{c}-0.944 * * \\
(0.446)\end{array}$ & \\
\hline Baka & & $\begin{array}{c}-2.369 \\
(1.485)\end{array}$ & $\begin{array}{c}-0.376 \\
(0.733)\end{array}$ & $\begin{array}{c}-0.299 \\
(0.690)\end{array}$ & $\begin{array}{c}-0.349 \\
(0.718)\end{array}$ & $\begin{array}{c}-0.298 \\
(0.675)\end{array}$ \\
\hline Tsimane' village 1 & & $\begin{array}{r}-2.502 * \\
(1.509)\end{array}$ & & $\begin{array}{l}4.407 * * * \\
(0.262)\end{array}$ & & $\begin{array}{l}4.404 * * * \\
(0.251)\end{array}$ \\
\hline Tsimane' village 2 & & $\begin{array}{l}-2.369 \\
(1.485)\end{array}$ & & $\begin{array}{c}0.159 \\
(0.204)\end{array}$ & & $\begin{array}{c}0.164 \\
(0.249)\end{array}$ \\
\hline Baka village 1 & & $\begin{array}{r}-2.501 * \\
(1.509)\end{array}$ & & $\begin{array}{c}-0.177 \\
(0.139)\end{array}$ & & $\begin{array}{r}-0.179 \\
(0.126)\end{array}$ \\
\hline Baka village 2 & & $\begin{array}{l}-3.319 * * \\
(1.502)\end{array}$ & & $\begin{array}{l}-0.803^{* * * *} \\
(0.170)\end{array}$ & & $\begin{array}{l}-0.811^{* * *} \\
(0.090)\end{array}$ \\
\hline Punan Tubu village 1 & & $\begin{array}{c}-1.344 \\
(1.466)\end{array}$ & & $\begin{array}{l}0.898^{* * *} \\
(0.149)\end{array}$ & & $\begin{array}{l}0.905^{* * *} \\
(0.224)\end{array}$ \\
\hline _cons & $\begin{array}{l}2.687 * * \\
(1.152)\end{array}$ & $\begin{array}{l}3.520 \\
(2.587)\end{array}$ & $\begin{array}{l}2.771 * * * \\
(0.959)\end{array}$ & $\begin{array}{l}2.191 * * * \\
(0.712)\end{array}$ & $\begin{array}{l}2.956 * * \\
(1.184)\end{array}$ & $\begin{array}{l}2.202 * * * \\
(0.843)\end{array}$ \\
\hline$R^{2}$ & 0.16 & 0.15 & 0.16 & 0.25 & 0.16 & 0.25 \\
\hline$N$ & 309 & 284 & 309 & 284 & 309 & 284 \\
\hline AIC & 1642.4909 & 1629.0291 & 1640.5253 & 1588.8383 & 1638.4960 & 1588.7361 \\
\hline $\mathrm{BIC}$ & 1679.8243 & 1661.8698 & 1677.8587 & 1621.6790 & 1675.8294 & 1621.5768 \\
\hline
\end{tabular}

tomorrow?" and "Will it be colder tomorrow than it is today?" Answering these questions was, however, not as straightforward as anticipated. When faced with the question, some informants said that there was no way to know and that "only God can tell." These might be so for at least two different reasons. First, by nature of their mobile lifestyle, the studied populations can gather ethnoclimatic information over areas larger than the ones covered by weather stations, which can result in a spatial mismatch between both measures (Marin 2010; Fernández-Llamazares et al. 2017). Second, researchers working on ethnoclimatological knowledge have argued that while this type of knowledge is based on factual and direct observations of biophysical phenomena, it is also largely perceptual, inherently tacit, and held in embodied experiential forms (i.e., not articulated in a form easily accessible to others; see Garay-Barayazarra and Puri 2011; Orlove et al. 2010). If so, it might be difficult for people to forecast or quantify weather changes, when just asked to do so, without the appropriate context, which might explain people's snags to answer our questions.

The second caveat of this work relates to the assumption of the model and the effect of omitted variable bias. Our model is based on many untested assumptions (e.g., people considered temperature and rainfall forecasts when planning daily activities; people have flexibility in choosing daily activities; people do not specialize in one activity; forest products are equally available across villages and households; people exert hunting/gathering effort to harvest efficiently, rather than for cultural or ceremonial reasons). Moreover, although our model included standard socioeconomic variables, it excluded potentially influential factors that might modify the direction and significance of the studied relation (i.e., access to and abundance and distribution of wild resources). Considering all the assumptions and omitted variable biases, our approach may represent an oversimplified analysis of the system, thus not allowing us to sufficiently assess the true relation between forecasting ability and returns to foraging.

The third caveat of this work relates to the crosscultural comparison. While the use of a cross-cultural sample increases our ability to generalize, it comes at some costs. The three studied societies are exposed to different climatic events, some of which might be more 
predictable than others. For example, the Tsimane' receive cold spells during the dry season (locally known as surazos), and the Punan Tubu can easily predict rain during the rainy season because it simply rains every day. Other society-specific traits might also affect peoples' ability to forecast weather. For instance, the selected societies do not generally use mass media to forecast weather, given that local radio programs (when they exist) do not generally transmit weather forecasts. However, the Tsimane' do have punctual access to some climatic information (i.e., the arrival of surazos) through local radios. While we tried to control for these specificities (i.e., by including different controls for village- and society-fixed effects), we cannot rule out the possibility that such differences drive some of the results found. These three caveats should be kept in mind when discussing the main findings of this work.

The first finding of this work is that values for our measures of consistency between people's ability to forecast rainfall and temperature and instrumental data are low. Indeed, only one informant displayed a high level of consistency both for rainfall and temperature forecasts. Interestingly, other than the village of residency, we did not find any significant socioeconomic correlation to our measures of consistency. There are two potential explanations to the finding that the village of residency is the most important correlate of our measures of consistency. On the one side, it is possible that this association is driven by specific weather conditions in each village. On the other side, it is also possible that the association is driven by the extent to which forecastings are shared in each village. Indeed, this explanation fits well with our ethnographic understanding of the study areas as we had observed that people often discuss the weather forecast with each other, as a way to plan their daily activities. For example, it is not uncommon for Tsimane' men to visit the neighbor's house in the morning and discuss upcoming activities. Neighborly discussions on climate are common among indigenous groups in Bolivia (e.g., Gilles and Valdivia 2009) and elsewhere (e.g., Orlove et al. 2010; Paul and Routray 2013; Hopping et al. 2016). So, if neighborly discussions on weather forecasts are more common in some villages than in others (because of households' geographical proximity, for example), then the finding that the village of residency is the variable most significantly associated with consistency is not surprising. Further research should explore the validity of these explanations.

A second important finding of this work is that people with higher consistency in forecasting rain are more likely to obtain some returns to time invested in hunting versus no returns at all. Indeed, it has been noted that rain forecast might discourage hunting because rain hampers hunters' ability to see or hear animals, undermines the smelling acuity of hunting dogs, and hardens hunters' ability to move through the forest (Godoy et al. 2009; Reed et al. 2011; Hušek et al. 2015). Moreover, on rainy days, many wild animals hide, making it hard for hunters to spot potential preys. If, indeed, rain affects hunting in such ways, then the association found is not surprising, as the inability to predict rain might result in hunters engaging in hunting trips during days when their chances to obtain a prey are low. Conversely, the ability to forecast rain is not associated with the actual hunting returns, probably because the actual capture of one prey or another is also contingent on many other factors (e.g., hunter's actual hunting skills).

Inversely, consistency in forecasting temperature does not relate in a statistically significant way either to the probability a person goes hunting or to hunting returns. It is possible that small changes in temperature might just not affect hunting activities in the same way than rain does. In the tropics, large changes in temperature are not frequent and small changes in temperature probably do not affect animal behavior in the same way as rain, for which hunting might be less affected by changes in temperature than by changes in rain. This hypothesis, however, will require more data to be tested.

A third finding of this work is that consistency in forecasting weather does not relate to returns to gathering. We do not have a robust explanation for this result, other than to speculate that people with a higher consistency in forecasting changes in weather might, indeed, be investing their time in activities other than gathering (e.g., agricultural tasks, fishing, wage labor). Gathering forest products is often considered a complement to the household's economy, a sort of safety net that can be activated when other activities are not successful, that is, when prey has not been captured in a hunting trip or to smooth consumptions when facing agricultural shocks (Rowland et al. 2017; Wunder et al. 2014). If so, then it is possible that people who are able to better forecast temperature are also better at allocating their time to alternative activities, whereas people less accurate in their forecast might have to resort to this safety net more often.

In sum, overall, our results do not show a very strong and consistent association between individual weather forecasting abilities (as narrowly measured through consistency with weather station data) and hunting and gathering returns. Beyond the methodological caveats presented above, one characteristic of the local knowledge system might also help interpret these results. Authors have argued that an important characteristic of local knowledge systems, including ethnoclimatological 
knowledge, is that they are widely shared and largely socialized through well-connected social networks (Reyes-García et al. 2003; Hopping et al. 2016; ReyesGarcía et al. 2016b). People in small-scale societies might decide how to allocate their time between different activities based on their weather forecast, but if individual weather observations are then contrasted with other people in the group (sometimes resulting in joint activities such as collective hunting trips), then it is not surprising that we do not find strong associations between consistency in forecasting weather and foraging returns. While our data do not allow testing the plausibility of this explanation, we propose it might be worth exploring further.

\section{Conclusions}

This work contributes to ethnoclimatological research in two different ways. First, we use an innovative method that allows us to estimate the consistency between an individual's weather forecast and instrumental data. Future research should aim to improve this method both by complementing individual forecasts with more contextual and ethnographic information in the design (and timing) of the questions and by collecting other climatic measurements related to ecosystem functioning variables linked to hunting/gathering, such as wind speed. Second, this research expands the focus of ethnoclimatological research from the study of ethnoclimatological knowledge and decision-making in agriculture and pastoral activities to include decisionmaking in hunting and gathering activities. While our results only show partial evidence of the importance of the association between consistency in weather forecasting and returns to hunting and gathering activities, it opens a new line of inquiry that will potentially gain prominence in the context of a changing climate.

Acknowledgments. The research leading to these results has received funding from the European Research Council under the European Union's Seventh Framework Programme (FP7/2007-2013)/ERC Grant Agreement FP7-261971-LEK (http://icta.uab.cat/Etnoecologia/ LEK/). This research adheres to the Code of Ethics of the International Society of Ethnobiology and received the approval of the ethics committee of the Universitat Autònoma de Barcelona (CEEAH-04102010). We extend our deepest gratitude to Baka, Punan Tubu, and Tsimane' individuals and villages for their friendship, hospitality, and collaboration. We thank V. Cuata, I. Díaz-Reviriego, R. Duda, S. Hadiwijaya, S. Huditz, L. Napitupulu, M. Pache, P. Pache, I.V. Sanchez, and D. Suan for help in data collection and A. Pyhälä for assistance in data coding and management. Reyes-García thanks ICRISAT-Patancheru for providing office facilities. This work contributes to the "María de Maeztu Unit of Excellence" (MdM-2015-0552).

\section{REFERENCES}

Altieri, M. A., and P. Koohafkan, 2008: Enduring Farms: Climate Change, Smallholders and Traditional Farming Communities. Environment and Development Series, Vol. 6, Third World Network, 62 pp.

Angelsen, A., and Coauthors, 2014: Environmental income and rural livelihoods: A global-comparative analysis. World Dev., 64, S12-S28, https://doi.org/10.1016/j.worlddev.2014.03.006.

Ayal, D. Y., S. Desta, G. Gebru, J. Kinyangi, J. Recha, and M. Radeny, 2015: Opportunities and challenges of indigenous biotic weather forecasting among the Borena herders of southern Ethiopia. SpringerPlus, 4, 617, https://doi.org/ 10.1186/s40064-015-1416-6.

Bahuchet, S., 1992: Dans la Forêt D'Afrique Centrale: Les Pygmées Aka Et Baka. Vol. 8. Peeters Publishers, 425 pp.

- 1993: History of the inhabitants of the central African rain forest: Perspectives from comparative linguistics. Tropical Forests, People and Food: Biocultural Interactions and Applications to Development, A. Hladik et al., Eds., Parthenon, 37-54.

Bjørnstadt, A., 2016: 'Do not privatize the giant's shoulders': Rethinking patents in plant breeding. Trends Biotechnol., 34, 609-617, https://doi.org/10.1016/j.tibtech.2016.02.007.

Brinkman, T. J., W. D. Hansen, F. S. Chapin, G. Kofinas, S. Burn Silver, and T. S. Rupp, 2016: Arctic communities perceive climate impacts on access as a critical challenge to availability of subsistence resources. Climatic Change, 139, 413-427, https://doi.org/10.1007/s10584-016-1819-6.

Brondizio, E. S., and E. F. Moran, 2008: Human dimensions of climate change: The vulnerability of small farmers in the Amazon. Philos. Trans. Roy. Soc. London, B363, 1803-1809, https://doi.org/10.1098/rstb.2007.0025.

Chicchón, A., 1992: Chimane resource use and market involvement in the Beni Biosphere Reserve, Bolivia. Ph.D. dissertation, University of Florida, 274 pp.

Duda, R., 2017: Ethnoecology of hunting in an empty forest. Practices, local perceptions and social change among the Baka (Cameroon). Ph.D. dissertation, Universitat Autònoma de Barcelona, $274 \mathrm{pp}$.

Fa, J. E., and Coauthors, 2016: Differences between pygmy and non-pygmy hunting in Congo basin forests. PLoS One, 11, e0161703, https://doi.org/10.1371/journal.pone.0161703.

Fernández-Llamazares, Á., I. Díaz-Reviriego, M. Guèze, M. Cabeza, A. Pyhälä, and V. Reyes-García, 2016: Local perceptions as a guide for the sustainable management of natural resources: Empirical evidence from a small-scale society in Bolivian Amazonia. Ecol. Soc., 21, 2, https://doi.org/ 10.5751/ES-08092-210102.

, R. A. García, I. Díaz-Reviriego, M. Cabeza, A. Pyhälä, and V. Reyes-García, 2017: An empirically tested overlap between indigenous and scientific knowledge of a changing climate in Bolivian Amazonia. Reg. Environ. Change, 17, 1673-1685, https://doi.org/10.1007/s10113-017-1125-5.

Ford, J. D., B. Smit, and J. Wandel, 2006: Vulnerability to climate change in the Arctic: A case study from Arctic Bay, Canada. Global Environ. Change, 16, 145-160, https://doi.org/10.1016/ j.gloenvcha.2005.11.007. 
Garay-Barayazarra, G., and R. K. Puri, 2011: Smelling the monsoon: Senses and traditional weather forecasting knowledge among the Kenyah Badeng farmers of Sarawak, Malaysia. Indian J. Tradit. Knowl., 10, 21-30.

Gautier-Hion, A., M. Colyn, and J. P. Gautier, 1999: Histoire naturelle des primates d'Afrique Centrale. ECOFAC, 162 pp.

Gilles, J. L., and C. Valdivia, 2009: Local forecast communication in the Altiplano. Bull. Amer. Meteor. Soc., 90, 85-91, https:// doi.org/10.1175/2008BAMS2183.1.

Godoy, R., and Coauthors, 2009: Does the future affect the present? The effects of future weather on the current collection of planted crops and wildlife in a native Amazonian society of Bolivia. Hum. Ecol., 37, 613-628, https://doi.org/10.1007/ s10745-009-9263-0.

Green, D., J. Billy, and A. Tapim, 2010: Indigenous Australians' knowledge of weather and climate. Climatic Change, 100, 337-354, https://doi.org/10.1007/s10584-010-9803-z.

Guèze, M., and L. Napitupulu, 2017: Trailing forest uses among the Punan Tubu of North Kalimantan, Indonesia. HunterGatherers in a Changing World, V. Reyes-García, and A. Pyhälä Eds., Springer, 41-58, https://doi.org/10.1007/ 978-3-319-42271-8_3.

, J. Paneque-Galvez, A. C. Luz, J. Pino, M. Orta-Martinez, V. Reyes-Garcia, and M. J. Macia, 2013: Determinants of tree species turnover in a southern Amazonian rain forest. J. Veg. Sci., 24, 284-295, https://doi.org/10.1111/ j.1654-1103.2012.01461.x.

Hair, J. F., Jr., 2010: Multivariate Data Analysis. 7th ed. Prentice Hall, 785 pp.

Hansen, W. D., T. J. Brinkman, M. Leonawicz, F. S. Chapin III, and G. P. Kofinas, 2013: Changing daily wind speeds on Alaska's North Slope: Implications for rural hunting opportunities. Arctic, 66, 448-458, https://doi.org/10.14430/arctic4331.

Hopping, K. A., C. Yangzong, and J. A. Klein, 2016: Local knowledge production, transmission, and the importance of village leaders in a network of Tibetan pastoralists coping with environmental change. Ecol. Soc., 21, 25, https://doi.org/ 10.5751/ES-08009-210125.

Hušek, J., M. Panek, and P. Tryjanowski, 2015: Test of precipitation, compensation and Monday effect hypotheses on group hare trapping effort. Wildland Biol., 21, 312-317, https:// doi.org/10.2981/wlb.00128.

Jiri, O., P. L. Mafongoya, C. Mubaya, and O. Mafongoya, 2016: Seasonal climate prediction and adaptation using indigenous knowledge systems in agriculture systems in southern Africa: A review. J. Agric. Sci., 8, 156-172, http://dx.doi.org/10.5539/ jas.v8n5p156.

Joiris, D. V., 1998: La chasse, la chance, le chant: Aspects du système rituel des Baka du Cameroun. Ph.D. dissertation, Université Libre de Bruxelles, 448 pp.

Kalanda-Joshua, M., C. Ngongondo, L. Chipeta, and F. Mpembeka, 2011: Integrating indigenous knowledge with conventional science: Enhancing localised climate and weather forecasts in Nessa, Mulanje, Malawi. Phys. Chem. Earth, 36, 996-1003, https://doi.org/10.1016/j.pce.2011.08.001.

Kaskija, L., 2012: Images of a Forest People, Punan Malinau: Identity, Sociality, and Encapsulation in Borneo. Vol. 52. Coronet Books, 270 pp.

Kijazi, A. L., L. B. Chang'a, E. T. Liwenga, A. Kanemba, and S. J. Nindi, 2013: The use of indigenous knowledge in weather and climate prediction in Mahenge and Ismani wards, Tanzania. J. Geogr. Reg. Plann., 6, 274-280, https://doi.org/10.5897/ JGRP2013.0386.
King, D. N. T., J. Goff, and A. Skipper, 2007: Māori environmental knowledge and natural hazards in Aotearoa-New Zealand. J. Roy. Soc. N. Z., 37, 59-73, https://doi.org/10.1080/ 03014220709510536.

Kingdon, J., 1997: The Kingdon Field Guide to African Mammals. Princeton University Press, $476 \mathrm{pp}$.

Kitanishi, K., 2006: The impact of cash and commoditization on the Baka hunter-gatherer society in southeastern Cameroon. Afr. Study Monogr., 33, 121-142.

Kolawole, O. D., M. R. Motsholapheko, B. N. Ngwenya, O. Thakadu, G. Mmopelwa, and D. L. Kgathi, 2016: Climate variability and rural livelihoods: How households perceive and adapt to climatic shocks in the Okavango delta, Botswana. Wea. Climate Soc., 8, 131-145, https://doi.org/ 10.1175/WCAS-D-15-0019.1.

Krupnik, I., and D. Jolly, Eds., 2002: The Earth is Faster Now: Indigenous Observations of Arctic Environmental Change. Arctic Research Consortium of the United States, $356 \mathrm{pp}$.

— C. Aporta, S. Gearheard, G. J. Laidler, and L. K. Holm, Eds., 2010: SIKU: Knowing Our Ice. Springer, 501 pp.

Leclerc, C., 2012: L'adoption de l'agriculture chez les pygmées Baka du Cameroun: Dynamique sociale et continuité structurale. MSH/Quae, 244 pp.

Lefale, P. F., 2010: Ua 'afa le Aso Stormy weather today: Traditional ecological knowledge of weather and climate. The Samoa experience. Climatic Change, 100, 317-335, https:// doi.org/10.1007/s10584-009-9722-z.

Levang, P., S. Sitorus, and E. Dounias, 2007: City life in the midst of the forest: A Punan hunter-gatherers' vision of conservation and development. Ecol. Soc., 12, 18, https://doi.org/10.5751/ ES-02036-120118.

Luseno, W. K., J. G. McPeak, C. B. Barrett, P. D. Little, and G. Gebru, 2003: Assessing the value of climate forecast information for pastoralists: Evidence from southern Ethiopia and northern Kenya. World Dev., 31, 1477-1494, https:// doi.org/10.1016/S0305-750X(03)00113-X.

Luz, A. C., 2013: The role of acculturation in indigenous people's hunting patterns: Implications for wildlife conservation. The case of the Tsimane' in the Bolivian Amazon. Ph.D. dissertation, Autonomous University of Barcelona, $150 \mathrm{pp}$.

—, M. Guèze, J. Paneque-Gálvez, J. Pino, M. Macía, M. Orta-Martínez, and V. Reyes-García, 2015: How does cultural change affect indigenous peoples' hunting activity? An empirical study among the Tsimane' in the Bolivian Amazon. Conserv. Soc., 13, 382-394, https://doi.org/10.4103/ 0972-4923.179879.

MacKinnon, K., G. Hatta, H. Halim, and A. Mangalik, 1996: The Ecology of Kalimantan. Periplus Editions, 802 pp.

Mapfumo, P., F. Mtambanengwe, and R. Chikowo, 2016: Building on indigenous knowledge to strengthen the capacity of smallholder farming communities to adapt to climate change and variability in southern Africa. Climate Dev., 8, 72-82, https://doi.org/10.1080/17565529.2014.998604.

Marin, A., 2010: Riders under storms: Contributions of nomadic herders' observations to analysing climate change in Mongolia. Global Environ. Change, 20, 162-176, https://doi.org/ 10.1016/j.gloenvcha.2009.10.004.

McElreath, R., and J. Koster, 2014: Using multilevel models to estimate variation in foraging returns: Effects of failure rate, harvest size, age, and individual heterogeneity. Hum. Nat., 25, 100-120, https://doi.org/10.1007/s12110-014-9193-4.

Moran, E., R. Adams, and B. Bakoyema, 2006: Human strategies for coping with El Niño related drought in Amazônia. 
Climatic Change, 77, 343-361, https://doi.org/10.1007/ s10584-005-9035-9.

Myers, P., R. Espinosa, C. S. Parr, T. Jones, G. S. Hammond, and T. A. Dewey, 2006: Animal diversity web. University of Michigan, http://animaldiversity.org.

Napitupulu, L., M. Gueze, and V. Reyes-García, 2016: Sharing in a context of rural development. A study among a contemporary hunter-gatherer society in Indonesia. Hunter-Gatherers in a Changing World, V. Reyes-García and A. Pyhälä, Eds., Springer, 127-147, https://doi.org/10.1007/978-3-319-42271-8_8.

Orlove, B., J. Chiang, and M. Cane, 2000: Forecasting Andean rainfall and crop yield from the influence of El Niño on Pleiades visibility. Nature, 403, 68-71, https://doi.org/10.1038/47456.

, C. Roncoli, M. Kabugo, and A. Majugu, 2010: Indigenous climate knowledge in southern Uganda: The multiple components of a dynamic regional system. Climatic Change, 100, 243-265, https://doi.org/10.1007/s10584-009-9586-2.

Osunade, A., 1994: Indigenous climate knowledge and agricultural practice in southwestern Nigeria. Malays. J. Trop. Geogr., 25, 21-28.

Paul, S. K., and J. K. Routray, 2013: An analysis of the causes of non-responses to cyclone warnings and the use of indigenous knowledge for cyclone forecasting in Bangladesh. Climate Change and Disaster Risk Management, W. L. Filho, Ed., Springer-Verlag, 15-40.

Payne, J., and C. M. Francis, 2007: A Field Guide to the Mammals of Borneo. Sabah Society, $332 \mathrm{pp}$.

Pearce, T., J. Ford, A. C. Willox, and B. Smit, 2015: Inuit traditional ecological knowledge (TEK) subsistence hunting and adaptation to climate change in the Canadian Arctic. Arctic, 68, 233-245, https://doi.org/10.14430/arctic4475.

Pepin, N., 1996: Indigenous knowledge concerning weather: The example of Lesotho. Weather, 51, 242-248, https://doi.org/ 10.1002/j.1477-8696.1996.tb06222.x.

Reed, S. E., A. L. Bidlack, A. Hurt, and W. M. Getz, 2011: Detection distance and environmental factors in conservation detection dog surveys. J. Wildland Manage., 75, 243-251, https://doi.org/10.1002/jwmg.8.

Reyes-García, V., and Coauthors, 2003: Ethnobotanical knowledge shared widely among Tsimane' Amerindians, Bolivia. Science, 299, 1707-1707, https://doi.org/10.1126/science.1080274.

— , and Coauthors, 2009: The pay-offs to sociability: Do solitary and social leisure relate to happiness? Hum. Nat., 20, 431-446, https://doi.org/10.1007/s12110-009-9073-5.

_ , J. Paneque-Galvez, P. Bottazzi, A. C. Luz, M. Gueze, M. J. Macia, M. Orta-Martinez, and P. Pacheco, 2014: Indigenous land reconfiguration and fragmented institutions: A historical political ecology of Tsimane' lands (Bolivian Amazon). J. Rural Stud., 34, 282-291, https://doi.org/10.1016/j.jrurstud.2014.02.007.

— A. Fernandez-Llamazares, M. Gueze, A. Garces, M. Mallo, M. Vila-Gomez, and M. Vilaseca, 2016a: Local indicators of climate change: The potential contribution of local knowledge to climate research. Wiley Interdiscip. Rev.: Climate Change, $\mathbf{7}$, 109-124, https://doi.org/10.1002/wcc.374.

_ , and Coauthors, 2016b: The adaptive nature of culture: A cross-cultural analysis of the returns of local environmental knowledge in three indigenous societies. Curr. Anthropol., 57, 761-784, https://doi.org/10.1086/689307.

Risiro, J., D. Mashoko, D. T. Tshuma, and E. Rurinda, 2012: Weather forecasting and indigenous knowledge systems in Chimanimani district of Manicaland, Zimbabwe. J. Emerging Trends Educ. Res. Policy Stud., 3, 561-566, http://hdl.handle.net/ 10520/EJC126539.

Roncoli, C., K. Ingram, and P. Kirshen, 2002: Reading the rains: Local knowledge and rainfall forecasting in Burkina Faso. Soc. Nat. Resour., 15, 409-427, https://doi.org/10.1080/ 08941920252866774.

Rosol, R., S. Powell-Hellyer, and H. M. Chan, 2016: Impacts of decline harvest of country food on nutrient intake among Inuit in Arctic Canada: Impact of climate change and possible adaptation plan. Int. J. Circumpolar Health, 75, 31127, https:// doi.org/10.3402/ijch.v75.31127.

Rowland, D., A. Ickowitz, B. Powell, R. Nasi, and T. Sunderland, 2017: Forest foods and healthy diets: Quantifying the contributions. Environ. Conserv., 44, 102-114, https://doi.org/ 10.1017/S0376892916000151.

Sellato, B., 2007: Resourceful children of the forest: The Kalimantan Punan through the twentieth century. Beyond the Green Myth: Borneo's Hunter-Gatherers in the Twenty-First Century, P. Sercombe and B. Sellato, Eds., NIAS Press, 61-90.

Sillitoe, P., 1994: Whether rain or shine: Weather regimes from a New Guinea perspective. Oceania, 64, 246-270, https://doi.org/ 10.1002/j.1834-4461.1994.tb02467.x.

Sollod, A. E., 1990: Rainfall variability and Twareg perceptions of climate impacts in Niger. Hum. Ecol., 18, 267-281, https:// doi.org/10.1007/BF00889156.

Soropa, G., S. Gwatibaya, K. Musiyiwa, F. Rusere, G. A. Mavima, and P. Kasasa, 2015: Indigenous knowledge system weather forecasts as a climate change adaptation strategy in smallholder farming systems of Zimbabwe: Case study of Murehwa, Tsholotsho and Chiredzi districts. Afr. J. Agric. Res., 10, 1067-1075, https://doi.org/10.5897/AJAR2013.7205.

Tengö, M., E. Brondizio, T. Elmqvist, P. Malmer, and M. Spierenburg, 2014: Connecting diverse knowledge systems for enhanced ecosystem governance: The multiple evidence base approach. Ambio, 43, 579-591, https://doi.org/10.1007/ s13280-014-0501-3.

Vadez, V., V. Reyes-García, T. Huanca, and W. Leonard, 2008: Cash cropping, farm technologies, and deforestation: What are the connections? A model with empirical data from the Bolivian Amazon. Hum. Organ., 67, 384-396, https://doi.org/ 10.17730/humo.67.4.45164623415rp7n8.

Wunder, S., J. Borner, G. Shively, and M. Wyman, 2014: Safety nets, gap filling and forests: A global-comparative perspective. World Dev., 64, S29-S42, https://doi.org/10.1016/ j.worlddev.2014.03.005.

Yasuoka, H., 2012: Fledging agriculturalists? Rethinking the adoption of cultivation by the Baka hunter-gatherers. Afr. Study Monogr., 43 (Suppl.), 85-114.

, 2014: Snare hunting among Baka hunter-gatherers: Implications for sustainable wildlife management. Afr. Study Monogr., 49, 115-136. 